\title{
Organizational identification and independent sales contractor performance in professional services
}

Article

Accepted Version

Finch, D. J., Abeza, G., O'Reilly, N. and Hillenbrand, C. (2018) Organizational identification and independent sales contractor performance in professional services. Journal of Services Marketing, 32 (4). pp. 373-386. ISSN 0887-6045 doi: https://doi.org/10.1108/jsm-07-2016-0278 Available at https://centaur.reading.ac.uk/75572/

It is advisable to refer to the publisher's version if you intend to cite from the work. See Guidance on citing.

To link to this article DOI: http://dx.doi.org/10.1108/jsm-07-2016-0278

Publisher: Emerald

All outputs in CentAUR are protected by Intellectual Property Rights law, including copyright law. Copyright and IPR is retained by the creators or other copyright holders. Terms and conditions for use of this material are defined in the End User Agreement.

www.reading.ac.uk/centaur 
Central Archive at the University of Reading

Reading's research outputs online 


\title{
Organizational identification and independent sales contractor performance in professional services
}

\author{
David Finch $^{\mathrm{a}}$, Gashaw Abeza ${ }^{\mathrm{b}}$, Norm O’Reilly ${ }^{\mathrm{c}}$, and Carola Hillenbrand ${ }^{\mathrm{d}}$
}

\author{
${ }^{a}$ Bissett School of Business \\ Mount Royal University \\ 4825 Mount Royal Gate SW, Calgary, AB, Canada, T3E 6K6 \\ E-mail: dfinch@mtroyal.ca \\ Tel: +1 403-560-0111 \\ (Corresponding author)

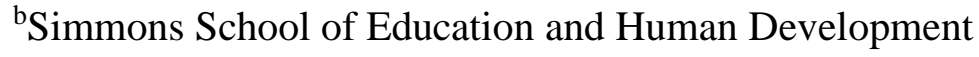 \\ Southern Methodist University \\ 3101 University Boulevard, Dallas, TX, U.S.A., 75205 \\ E-mail: gabeza@smu.edu \\ Tel: +1 469-951-6951 \\ ${ }^{\mathrm{c}}$ Department of Sports Administration \\ College of Business, Ohio University \\ 1 Ohio University, Athens, OH, USA, 45701 \\ E-mail: oreillyn@ohio.edu \\ Tel: +1 740-593-9319 \\ ${ }^{\mathrm{d}}$ Henley Business School \\ University of Reading \\ Greenlands, Henley-on-Thames, Oxfordshire, \\ RG9 3AU, UK \\ Email: carola.hillenbrand@henley.ac.uk \\ Tel: +44 (0)1491571454
}


ANTECEDENTS OF INDEPENDENT SALES CONTRACTOR PERFORMANCE 2

\section{Introduction}

The ability to adapt and respond quickly to changing competitive dynamics is of increasing importance to managers (De Cuyper \& De Witte, 2007; King \& Burgess, 2008), who, in turn, employ a variety of workforce models that enable them to adapt to these changing pressures (Pass, 2015; Rapp, Agnihotri, \& Baker, 2015). An important shift is the increasing use of non-permanent labor/employment, referred to as externalization (Bidwell \& Briscoe, 2009; Lepak \& Snell, 2002). A recent report indicates that, as of 2015, there are 17.8 million full-time independent workers in the United States, a growth of 26\% since 2011 (MBO Partners, 2015). The report further notes that the number of independent workers is growing at rate 5 times greater than that of full-time jobs and that it is expected to continue to grow (MBO Partners, 2015).

An important dimension of externalization, and the focus of this study, is the emergence of the independent sales contractor (ISC) distribution model in several industries, including pharmaceutical, food and restaurant, industrial sales, utility, agriculture, construction, hospitals, medical, financial services, and real-estate (Finch et al., 2015; US Bureau of Labor Statistics, 2012). ISC's are independent agents who sell products or services to a customer base, defined by the firm with which they are under contract (Pass, 2015). Importantly, the contracting companies neither control how the contractors/representatives manage their work, nor do they make longterm employment commitments or offer non-financial benefits to the ISC's, unlike they do when hiring a full-time salesperson (Johnson \& Ashforth, 2008). The ISC's financial compensation typically involves sales commission, either at a $100 \%$ commission or a mixed model with a base salary. This performance-based compensation structure allows the contracting firm to incentivize an ISC to align their goals to those of the firm (Banker, Lee, Potter \& Srinivasan, 1996; Mallin \& 


\section{ANTECEDENTS OF INDEPENDENT SALES CONTRACTOR PERFORMANCE 3}

Pullins, 2009). The benefit for a contracting firm is that they can significantly expand the depth and reach of their distribution capacity without adding full-time sales staff (Slater \& Olson, 2000). The benefit for the ISC is that their compensation directly reflects performance, while they retain the independence many have been shown to seek (Bidwell \& Briscoe, 2009; Finch et al., 2015).

To date, scholars have explored many factors that influence ISC-level outcome, such as ISC sales performance, ISC retention, and ISC advocacy. First, the sales and marketing literature (e.g., Mallin \& Pullins, 2009; VandeWalle et al. 1999) identifies sales performance (often measured as units sold by an ISC or commission paid to an ISC) as an important outcome for both the ISC and the firm as sales performance directly influences ISC compensation and firm revenues and profitability. Second, ISC retention (i.e., maintaining a contractual relationship with a firm) is an important outcome as higher retention has been shown to positively influence a firm performance (Katsikea \& Morgan, 2014). Finally, ISC advocacy is an important firm outcome. ISC advocacy is when an ISC actively supports and defends the firm to which they are contract (Borman \& Motowidlo, 1997; George, Levenson, Finegold, \& Chattopadhyay, 2010). Scholars also identify advocacy as a component of the construct of organizational citizenship behaviour (Borman \& Motowidlo, 1997), and as a standalone construct (Hillenbrand, Money, \& Ghobadian, 2013). Advocacy and citizenship behaviour can be considered to be related to the concept of organizational identification.

Organizational identification is defined as "perceived oneness with an organization and the experience of the organization's success or failures as one's own” (Mael \& Ashforth, 1992, p. 103). The role of organizational identification is of unique as an ISC possesses the dual identity of an independent agent and that of a sales representative of the firm to which s/he is under contract. Previous research has examined factors that influence ISC-level outcomes (sales 


\section{ANTECEDENTS OF INDEPENDENT SALES CONTRACTOR PERFORMANCE 4}

performance, retention and advocacy), including resources (e.g. competitive intelligence collection and use) (Rapp, Agnihotri, \& Baker, 2015), trust (e.g., the role of communication quality) (Pass, 2015; Rich, 1997), embeddedness (Crossley, Bennett, Jex \& Burnfield, 2007) and

personality (e.g., conscientiousness) (Barrick, Mount, \& Strauss, 1993). Notably, research on the impact of organizational identity on ISC-level outcomes is limited and represents a gap in the extant literature. Thus, the current study develops and tests the antecedents of organizational identification and its influence on ISC-level outcomes.

Management scholars argue that the interaction between the individual and organizational identification is iterative, whereas the identity of the individual becomes intertwined with that of the organization (Ashforth et al., 2008; Gioia \& Chittipeddi, 1991). Several research works (e.g., Burke \& Tully, 1977; Ibarra, 1999; Riketta, 2005) demonstrate that organizational identification is a dynamic process that offers meaning and guidelines to support an individual's actions. While some argue that identity is a zero-sum phenomenon in which one identity exists at the expense of others (Turner, Hogg, Oakes, Reicher \& Wetherell, 1987), some scholars argue that it is possible for an individual to possess multiple complementary identities (Ashforth \& Johnson, 2001; Barker \& Tompkins, 1994; Hornsey \& Hogg, 2000). Thus, organizational identification may influence whether an ISC chooses to work with specific firms and how different incentives link to performance dimensions of ISCs.

By exploring the influence of organizational identification on ISC-level outcomes in professional services, this research contributes to literature associated with organizational identity, services marketing and sales management. It also offers guidance to the managers of ISCs by examining the factors that influence ISC-level outcomes. To accomplish this, we employ a quantitative research design that empirically tests hypotheses using structural equation modeling (SEM) in a study of 189 ISCs of a professional services firm. It is worth mentioning 


\section{ANTECEDENTS OF INDEPENDENT SALES CONTRACTOR PERFORMANCE 5}

here that the study is based on actual ISC behavioral data over a six-year period including: ISC sales performance (e.g. unit sales), ISC retention over the full study period, and ISC advocacy (e.g. referral commission payments).

\section{ISCs and organizational identification}

Scholars argue externalization offers a firm maximum flexibility in the face of competitive pressures during periods of expansion or contraction, without having to make longterm commitments to workers while enhancing innovation by engaging perspectives not influenced by internal culture (De Cuyper \& De Witte, 2007; Davis Blake \& Uzzi, 1993). The decision to adopt externalization as a workforce model is influenced by a variety of contextual factors such as the demand for a specific skill-set, occupational differentiation, technology and the value of skills to a firm (Lepak \& Snell, 2002). Scholars observe that externalization has extended into the professional services sector (Ellram, Tate \& Billington, 2008); in fact, organizations in the service sector are increasingly relying on externalized contractors (Walsh \& Deery, 2006) and the majority perceive externalized employment beneficial (Johnson \& Ashforth, 2008).

Professional services, in general, include diverse fields such as accountancy, advertising, architectural, medical/health, recruitment, insurance brokerage, investment banks, legal, management consultancy, media production, medical information, real-estate brokerages, research and development laboratories and software design (Brandon-Jones, Lewis, Verma \& Walsman, 2016; Finch et al., 2015; Koku, 2015). Brandon-Jones, Lewis, Verma and Walsman (2016) contend that professional services firms share several common operational traits including significant levels of customer engagement, customization, knowledge intensity and relatively low capital investment. However, externalization in professional services involves 


\section{ANTECEDENTS OF INDEPENDENT SALES CONTRACTOR PERFORMANCE 6}

some unique management challenges including: quality control and consistency, ensuring a positive customer experience, recruiting/retaining staff and staff training (Brandon-Jones, Lewis, Verma \& Walsman, 2016; Schmenner, 1986). One challenge in professional services is the iterative nature of the engagement and service customization between a firm and its clients. This iterative engagement and service customization highlights the important role of expert knowledge for client facing staff in professional services (Brandon-Jones, Lewis, Verma \& Walsman, 2016). As Ellram, Tate and Billington (2008) also identify, one of the risks of externalization in professional services is the loss of tacit knowledge within the firm.

These unique dynamics offer an important research context to study the use of ISCs in professional services that allows a contribution to be made to the advancement of both theory and practice. Similar to the field of professional services, the role of the ISC involves its own unique features. In some cases, ISCs may sell for multiple firms (e.g. selling multiple financial services/products), but in others they may have an exclusive sales relationship with a single firm (e.g. selling only one firm's services). Researchers identify the challenge of aligning sales motivation to incentives as a major challenge for any firm (Ramaswami \& Singh, 2003), but this becomes even more challenging when managing a sales force composed whole or in-part of ISCs.

In their empirical study of ISCs, Finch et al. (2015) identify incentives as including both transactional and relational dimensions. Moreover, they demonstrate that an ISCs perception of dependency on the contracting firm as influencing ISC behaviour. Finch et al. (2015 p. 9) state: "sales contractors may believe that their success is dependent on the identity and reputation of the firm, and may, therefore, work harder to achieve sales in the name of the firm, as they may believe they will only be successful in association with the firm". Previous literature examines 


\section{ANTECEDENTS OF INDEPENDENT SALES CONTRACTOR PERFORMANCE 7}

the influence of organizational identification on broader contractor-level outcomes, such as sales performance, retention, and advocacy (George, Levenson, Finegold \& Chattopadhyay, 2010).

Identity is considered from a range of theoretical lenses including role identity (Stryker \& Burke, 2000), self-regulation (Markus \& Wurf, 1987), self-categorization (Turner et al., 1987) and social identity (Tajfel \& Turner, 1986). A central argument of social identity theory (cf. Dutton, Dukerich \& Harquail, 1994; Tajfel \& Turner, 1986) is that individuals classify themselves and others into various categories to make sense of the social world and their place in it. Social identity is, therefore, the portion of an individual's self-perception that arises from membership in a particular group or groups, as well as the emotional significance and value attached to the membership (Abeza, O’Reilly \& Nadeau, 2014). Relatedly, self-categorization (Turner et al., 1987) explains the dual nature of individualism — when people view themselves as individuals and at other times when they believe they are part of a group. Self-categorization, therefore, shapes one's sense of self, cognitively allowing one to form casual and formal associations with in- and out-groups based on demographics, personalities, and beliefs (Abeza et al., 2014). As Grieve and Hogg (1999) and Hogg and Terry (2000) add, an individual's identity may displace that of the social group, whereas they adapt their attitudes and behaviors to align with the identity of the group. In such contexts, identification is a cognitive construct in which the individual feels psychologically linked to a group, but it is distinct from behavior and affect (Ashforth \& Mael, 1989).

A growing but diverse body of research exists on the topic of organizational identification (Ashforth, Harrison, \& Corley, 2008).. Since March and Simon (1958) proposed the first detailed model of organizational identification (Riketta, 2005), researchers in organizational behavior, social psychology, and communication revisited organizational identification as a unique construct, and introduced different definitions of the construct 


\section{ANTECEDENTS OF INDEPENDENT SALES CONTRACTOR PERFORMANCE 8}

(Ashforth, Rogers \& Corley, 2010; Riketta, 2005). According to Ashforth, Rogers and Corley (2010), organizational identification is the degree to which one identifies her/himself with a specific organization and the value that s/he attaches to that self-definition. Comprehensively, Patchen (1970) defines organizational identification as "a variety of separate, though related phenomena ... (1) feelings of solidarity with the organization; (2) [attitudinal and behavioral] support for the organization; and (3) perception of shared characteristics with other organizational members"' (p. 155). Building on the foundational works on identity, management literature considers the link between the individual and organizational identification (Ashforth, Rogers \& Corley, 2010; Riketta, 2005). Mael and Ashforth (1992) define organizational identification as the "perception of oneness with, or belongingness to, an organisation where the individual defines him/herself in terms of the organisation in which he or she is a member" (p. 105). In a meta-analysis of the organizational identification literature, Riketta (2005) finds most definitions of organizational identification are rooted in an individual's self-concept, either cognitively (e.g., feeling a part of the organization; internalizing organizational values), or emotionally (pride in membership), or both.

Previous management research examines the influence of organizational identification by a variety of stakeholders (e.g. employees, suppliers) on organizational performance (Ashforth, Harrison \& Corley, 2008; Corsten, Gruen \& Peyinghaus, 2011). This includes Drori and Ellis (2011), who examine sense making, power, and conflict in the context of a multinational organizations by considering the influence of headquarters, subsidiaries, and geographic regional identities. Studies also explore the influence of sense making and sense giving within a variety of corporate contexts (e.g., Gioia \& Thomas, 1996; Landau \& Drori, 2008; Maitlis \& Lawrence, 2007). 


\section{ANTECEDENTS OF INDEPENDENT SALES CONTRACTOR PERFORMANCE 9}

Moreover, scholars examine the complexity and multi-level nature of identity and identification (Corsten, Gruen \& Peyinghaus, 2011). For example, employees are not only members of a firm, they are also members of departments and/or workgroups (DeConinck, 2011). Similarly, Corsten, Gruen and Peyinghaus (2011) explore the influence of interorganizational identification of suppliers with their buyers. Researchers (e.g., Vora \& Kostova, 2007) highlight the challenge of role conflict, recognizing that social identity is a composite of a variety of identities. Previous studies consider the conflictual or complementary nature of organizational identification when an individual is a member of two or more organizations or social groups. Scholars debate the nature and implications of multiple identities. For example, Turner et al. (1987) argues that the adoption of one identity must be at the expense of others; they deem this phenomenon "functional antagonism". As Ashforth and Johnson (2001) note, this approach suggests that "social identities are discrete psychological phenomena such that as one identity becomes salient, others necessarily become less so" (Ashforth \& Johnson, 2001: 46). However, others challenge this zero-sum paradigm and argue that it is possible to possess multiple identities that are complementary and possess common values that mitigate cognitive dissonance (Barker \& Tompkins, 1994; Hornsey \& Hogg, 2000). The alignment of these identities is important as identity is a cognitive representative of oneself and therefore alignment is essential to guide attitude formation (e.g., goals) and behaviors (Markus \& Nurius, 1986). Moreover, Ashforth and Mael (1989) argue that a sub-unit, such as a department, could prove to be an effective conduit for managing these challenges as it incorporates both interpersonal identity has a higher probability to common task orientation. Finally, scholars examined how different internal organizational structures - such as face-to-face teams, pure virtual teams and hybrid teams contribute to identity (Fiol \& O’Connor; 2005). Specifically, Wiesenfeld, Raghuram and Garud (2001) found an employee's need for affiliation, combined 
with work-based social supports, amplifies organizational identification amongst workers on a virtual team.

However, to date, limited research examines organizational identification in the context of contractors. Hence, this study examines the antecedents of organizational identification and its influence on ISC-level outcomes. In one of the few studies on the topic, George and Chattopadhyay (2005) examine the influence of organizational identification on contract workers who are employed by a firm as consultants but who are located at a client site. The authors report that the contractor firm is the dominant organizational identification, but the client organizational identification is also influential. In addition, research on contractors, suggests that organizational identification influences both citizenship behaviors (Mael \& Ashforth, 1992) and intraorganization cooperation (Dutton et al., 1994). A number of scholars also examine the factors that contribute to organizational identification. These factors include financial benefits (e.g., Millward \& Postmes, 2010; Wieseke, Ahearne, Lam \& van Dick, 2009), operational benefits (e.g., Edwards, 2009; Edwards \& Peccei, 2010), marketing benefits (e.g., Dukerich, Golden, \& Shortell, 2002) and value congruence (e.g., Charbonnier- Voirin, Poujol, \& Vignolles, 2016). The following section will review the hypotheses development that guides our empirical study.

\section{Hypotheses development}

In developing the frame for this research, we isolate four uni-dimensional antecedents of organizational identification previously identified in the literature: (1) financial benefits, (2) operational benefits, (3) marketing benefits, and (4) value congruence. Below, we define each construct and our proposed hypotheses for each.

\section{Financial benefits}

Financial benefits incorporate the direct and perceived financial benefits related to an exchange and may include a combination of fixed and variable compensation and additional 


\section{ANTECEDENTS OF INDEPENDENT SALES CONTRACTOR PERFORMANCE 11}

benefits depending on the context (Stajkovic \& Luthans, 2001). To date, limited research has investigated the financial benefits that contribute to organizational identification. For example, Millward and Postmes (2010) demonstrate the quantifiable sales benefit (in terms of sales volume) of organizational identification. Wieseke, Ahearne, Lam and van Dick (2009), in their part, report that the stronger sales managers and sales representatives identify themselves with an organization, they are "more likely to reach a higher level of sales quota achievement and to perform more effectively" (p. 37). In the context of contractors, financial benefits are of importance due to lower commitment levels (Ang, Slaughter \& Ng, 2002), high self-interest (George et al., 2010), and decreased job security (Leana \& Rousseau, 2000). However, the overall effectiveness of financial benefits as drivers of behavioral outcomes is widely debated in psychology (Bandura, 1986; Eisenberger, Huntington, Hutchison \& Sowa, 1986), sociology (Granovetter, 1973), marketing (Morgan \& Hunt, 1994; Palmatier et al., 2006a), organizational theory (Stajkovic \& Luthans, 2001), and strategic management (Pfeffer \& Nowak, 1976). In this study, we follow Stajkovic and Luthans (2001) and define financial benefits as the real or perceived financial benefits an ISC receives from the firm (e.g. financial compensation, switching costs). Consequently, we predict that ISC satisfaction with their financial benefits will positively predict their levels of organizational identification.

H1. ISC satisfaction with financial benefits will be positively related to organizational identification.

\section{Operational benefits}

In a similar manner, the extent to which a firm extends its operational support to employees tends to positively impact the employee organizational identity (Edwards \& Peccei, 2010). For example, ISCs may benefit from centralized operational support provided by the firm, including information technology, professional development, administration, and office space 
(Grace \& Weaven, 2011; Monroy \& Alzola, 2005). As a result, the study predicts that an ISCs satisfaction with the operational support (e.g. information technology) provided by the firm contributes to organizational identification.

H2. ISC satisfaction with operational benefits will be positively related to organizational identification.

\section{Marketing benefits}

Scholars report that employees seek to give back to the organization that helped them achieve their socio-emotional needs (He \& Brown, 2013). As Dukerich, Golden, and Shortell (2002) discuss, the perceived organizational identity attributes, that are commonly conceptualized as the key antecedents of employee organizational identification, include prestige, construed external image, distinctiveness, etc. In the context of ISCs, one of the most important benefits for the contractor is the ability to leverage the brand equity and reputational capital of the contracting firm (Monroy \& Alzola, 2005). This is often operationalized through centralized firm-level marketing benefits including firm-level advertising and branding (Monroy \& Alzola, 2005). Consequently, the study predicts that satisfaction with marketing benefits will be related to organizational identification.

H3. ISC satisfaction with marketing benefits will be positively related to organizational identification.

\section{Value congruence}

Scholars identify value congruence as an important relational criterion. As Saks and Ashforth (1997) contend, individuals who perceive congruence with their organization tend to define themselves along the same lines of the organization. Value congruence, according to Edwards and Cable (2009), leads individuals to be more productive and committed to the organization they associated with, and more likely to go above and beyond their duties to support 


\section{ANTECEDENTS OF INDEPENDENT SALES CONTRACTOR PERFORMANCE 13}

the values of an organization with which the individual aligns. In this work, value congruence is considered as a fit between a firm's core beliefs, principles, vision, and leadership and those of the contractor (Kennedy, Goolsby \& Arnould, 2003), and reflecting alignment between the firm's core value and those of the ISC (Fombrun, Gardberg \& Sever, 2000). The study anticipates that value congruence will predict organizational identification.

H4. ISC value congruence will be positively related to organizational identification.

\section{ISC embeddedness}

The concept of job embeddedness is highlighted in the management literature (Jaramillo, Mulki \& Boles, 2012). It is important to note, however, that the construct of "job embeddedness" in management literature is distinct from the construct of "embeddedness" used by social network theorists. Specifically, job embeddedness considers factors such as job fit, value of community, interpersonal links and the sacrifice an individual would make in terminating a relationship with a firm (Felps et al, 2009; Mitchell et al., 2001). Previous studies demonstrate that job embeddedness influences employee turnover (Crossley, Bennett, Jex \& Burnfield, 2007). In the context of an ISC, Finch et al. (2015) argue that job embeddedness is rooted in a psychological contract between an ISC and the firm. Similarly, Stamper and Masterson (2002) identified PIS as influencing employer behaviour. As a result, we hypothesize that an ISC's embeddedness positively influences their behaviours related to retention (when an ISC chooses to maintain a commercial relationship with a firm) and advocacy (when an ISC chooses to actively endorse, support and defend a firm ${ }^{1}$ ). In sum:

H5a. ISC embeddedness will be positively related to retention.

H5b. ISC embeddedness will be positively related to advocacy.

\footnotetext{
${ }^{1}$ Refer to George, Levenson, Finegold, \& Chattopadhyay, 2010
} 
ANTECEDENTS OF INDEPENDENT SALES CONTRACTOR PERFORMANCE 14

Organizational identification

Previous research demonstrates a relationship between organizational identification and employee-level outcomes (George, Levenson, Finegold \& Chattopadhyay, 2010). Moreover, organizational identification literature suggests that this construct contributes to increased interdependence between an individual's identity and that of the firm (Ashforth, Rogers and Corley, 2010). Based on this, we propose that organizational identification among ISCs will be positively related to ISC embeddedness and ISC sales performance:

H6a. Organizational identification will be positively related to ISC embeddedness.

H6b. Organizational identification will be positively related to ISC sales performance.

\section{Sales performance}

Previous studies find that sales performance may influence agent retention (Futrell \& Parasuraman, 1984) and future success (Slater \& Olson, 2000). Moreover, research suggests that relational satisfaction (including fulfilling relational expectations) may influence advocacy (Hillenbrand, Money \& Ghobadian, 2013; Podsakoff et al., 2009). Therefore, the study hypothesizes:

H7a. ISC sales performance of the ISC will be positively related to retention.

H7b. ISC sales performance of the ISC will be positively related to advocacy. Refer to Figure 1 for a summary of the proposed relationship among the variables in the model and the associated hypotheses.

\section{**INSERT FIGURE 1 ABOUT HERE**}

\section{Methodology}

The above hypotheses were tested through SEM based on data collected over a six-year period from a privately held Canadian professional services firm (in the real-estate sector) and its 
650 ISCs. The firm services one geographic region and the ISCs are the sole distribution channel, thus their performance is essential to the firm. At this firm, ISCs are on a one-year, performance-based $100 \%$ commission contracts. The contract can be renewed with the consent of both parties. The contract includes a non-competition provision which states that the ISC cannot sell products or services for a firm in the same category. The ISCs at this firm are required to pay a mandatory monthly fee to access a range of services including information technology, office space and marketing, and administration support. As mentioned above, the study is based on actual behavioral data for each of the 189 ISCs over a six-year period. This includes actual sales performance data (e.g. unit sales), retention data (remained with the firm) and advocacy data (e.g. referral commission payments). SEM was chosen as the statistical technique for this study because it allows us to test simultaneously the relationship of the multiple variables (both dependent and explanatory) in the model (Lei \& Wu, 2007). Moreover, it enables us to test the relationship between traditionally non-measureable constructs through the use of non-experimental data (Lei \& Wu, 2007). As a confirmatory technique, SEM requires that a theoretical model first be developed and empirically tested (Lei \& Wu, 2007). This confirmatory technique is suited to test the validity of the proposed model. SEM included three major stages: (a) an estimation of the model parameters; (b) an evaluation of the model through goodness-of-fit tests; and (c) a test of the hypothesized relationships using standardized regression. The methodology and results will now be reviewed.

\subsection{Instrumentation development \& piloting}

For the development of the measures, we referenced the works of Churchill (1979), Rossiter (2002) and Podsakoff et al. (2003). We began the instrument design process by examining the published measures used in marketing and management studies. The studies referenced during development of our pilot instrument include Mael and Ashforth's (1992) 
ANTECEDENTS OF INDEPENDENT SALES CONTRACTOR PERFORMANCE 16

(organizational identification); Lacey’s (2007) relational constructs (trust, commitment, economic value, switching costs, shared value) and MacMillan, Money, Downing and Hillenbrand's (2005) relational antecedents (material and non-material benefits, termination costs, shared values, trust, commitment) and outcomes (cooperation, loyalty, advocacy); Morgan and Hunt (1994) commitment-trust instrument (relational benefits, shared values, commitment, trust, retention); and Fombrun et al.’s (2000) reputation instrumentation (quality, trust). The initial pilot instrument incorporated a minimum of five observed variables for each of the constructs (exceeding the minimum of three recommended by Mazzocchi, 2008).

All latent variables were measured on a Likert scale ranging from 1 (strongly disagree) to 5 (strongly agree) (per Posner \& Schmidt, 1993). To refine the instrumentation, a series of pilot interviews with the management of the firm to ensure maximum clarity for the target audience was first conducted. Following these interviews, the researchers conducted a pre-test study of the instrumentation with a sample of 40 ISCs. The pre-test enabled further refinement of the instrumentation, including the removal of some redundant questions and the rewording of others, allowing us to proceed to the full study phase (refer to Table 1 for the final measures). Lastly, following Finch et al. (2015), we incorporated gender, age, education and length of time with the firm as control variables. In addition, we controlled for two additional variables in our model (a) ISC trust in firm management; and (b) ISC historic sales performance.

To distribute the full survey instrument, the management of the firm informed, via email, the target population of ISCs active with the firm. The communication outlined that the research project is university sponsored, and that the firm would only receive summary statistics of aggregated data to assure ISC confidentiality. Surveys were distributed and collected through a self-administered, web-based process. Participants were requested to provide their mobile numbers allowing us to match survey responses with individual ISC sales performance and 
retention data, while maintaining anonymity. The final survey sample consisted 189 ISCs (survey data with matching sales performance and retention records), which represents a response rate of 29\%, an acceptable level (per Baruch, 1999). Slightly more participants were male (59\%) than female (41\%). Their average age was 46 years old and they have been an ISC for an average of 7.8 years (an average of 5.6 years with the current firm). A total of $75.4 \%$ of respondents had a diploma or degree. The participant's annual income ranged from earning less than $\$ 20,000(11.8 \%)$ to earning greater than $\$ 150,000(13.8 \%)$.

To examine the constructs in the model, the researchers conducted both EFA and CFA on the data (Zoghbi-Manrique-de-Lara, 2010). The EFA was conducted on the full data set using principal components extraction and a varimax rotation to assess discriminant validity. The final instrument included 25 manifest variables that were designed to measure the consistent characteristics of the latent constructs in the model. The study proceeded to the second stage of the data analysis and conducted CFA on each of the eight latent variables (Hair, Anderson, Tatham \& William, 1998). Table 1 presents the CFA results. The fit statistics were favorable relative to common standards (Vandenberg \& Lance 2000). All variables loaded as unidimensional constructs with acceptable goodness-of-fit indices, with regression weights in excess of the minimum 0.40 (Blunch, 2008). Moreover, the Cronbach's alpha for each composite construct exceeded the minimum of 0.60 (Bagozzi \& Yi, 2012). Based on these results, it is concluded that the five latent variables incorporated in the hypothesized model maintained were both valid and reliable representations of each construct.

\section{**INSERT TABLE 1 ABOUT HERE**}

\subsection{Archival sales performance data}

The firm provided coded archival sales performance data for each of the 189 ISCs over the six-year period. The sales performance data were matched with ISC survey responses by 
mobile phone numbers. The sales performance data is based on total units sold and were divided into two three-year groups to reflect the 'pre' and 'post' nature of the research design. The retention measure considered reflected whether they left the firm on their own volition in the three years following the survey. The advocacy measure is based on the actual commission payments made to the ISC for referring new ISCs to the firm during the full six-year period of the study. Finally, years of service is based on the number of years an ISC had been under contract with the firm.

\subsection{Model analysis}

The next step in the analysis was to examine the hypothesized relationships amongst the eight variables. The correlational table (Table 2) provides a summary of the descriptive statistics (including the Mean, Standard Deviation and AVE) of the constructs incorporated into the model.

\section{**INSERT TABLE 2 ABOUT HERE**}

As suggested by Morgan and Hunt (1994), the correlation table provides preliminary guidance on the relationship between the constructs in the model. Firstly, the average variance extracted (AVE) of all measure is above the recommended level of .5 (Fornell \& Larcker, 1981), confirming satisfactory convergent validity. The construct of ISC embeddedness is positively related to organizational identification and ISC trust in firm management. Also, there is a positive relationship between ISC embeddedness and historic sales performance and advocacy. As anticipated, post-sales performance is strongly related to historic sales performance and advocacy. However, there is no significant relationship between ISC embeddedness and postsales performance as the study had hypothesized. Interestingly, the years an ISC had been with the firm is only related to historic performance and retention, but to no other variables in the model. 
The final phase of the analysis involved conducting a multiple regression analysis of the hypothesized relationships in the model using AMOS 21. The hypothesized model (Figure 2) confirmed goodness of fit $(\mathrm{CFI}=0.967, \mathrm{TLI}=0.962, \mathrm{CMIN} / \mathrm{DF}=1.272, \mathrm{RMSEA}=0.036, \mathrm{AIC}$ $=569.694)$. The $R^{2}$ for the endogenous variables in the final model are as follows: organizational identification $\left(R^{2}=0.853\right)$; ISC embeddedness $\left(R^{2}=0.899\right)$; sales performance $\left(R^{2}=0.528\right)$; retention $\left(R^{2}=0.242\right)$; advocacy $\left(R^{2}=0.028\right)$. It is important to note that some of the nonsignificant correlations from the univariate analysis (e.g., advocacy and sales performance) interact significantly in the multivariate analysis (Figure 2) supporting that multivariate analyses are essential in complex contexts such as the ISC-firm relationship. ${ }^{2}$

\section{**INSERT FIGURE 2 ABOUT HERE**}

\subsection{Summary of results}

Refer to Table 3, for a summary of the hypotheses and the associated result.

**INSERT TABLE 3 ABOUT HERE**

\section{Discussion}

This research sought to respond to the gap in the literature about organizational identity as a factor in ISC-level outcomes. Recent evidence shows that the ISC distribution model has expanded into a variety of sectors, including pharmaceutical, medical, financial services, and real-estate (US Bureau of Labor Statistics, 2012). Moreover, research (Finch et al., 2015; George, Levenson, Finegold \& Chattopadhyay, 2010) called for inquiry into the antecedents of ISC-level outcomes. Our central contribution is synthesizing social identity (Tajfel \& Turner,

\footnotetext{
${ }^{2}$ Consistent with Gummerus, Liljander, Pura \& Van Riel (2004) we tested a rival model. Chin, Peterson, and Brown (2008) noted that it is essential that SEM be theoretically driven. Our rival hypothesized model predicted that the variables financial benefits, operational benefits, marketing benefits and value congruence directly predicted sales performance, embeddedness, advocacy and retention. This rival model failed to possess an acceptable goodness of fit.
} 
ANTECEDENTS OF INDEPENDENT SALES CONTRACTOR PERFORMANCE 20

1986) and organizational identification (Ashforth \& Mael, 1989) to develop and test a model exploring the antecedents of ISC-level outcomes. We contend that an ISCs own identity is intrinsically linked to the organizational identity of the firm to which they are contracted. Specifically, we argue that financial benefits, operational benefits, marketing benefits and value congruence are antecedents of this organizational identification. Moreover, we contended that organizational identification systematically predicts ISC-outcomes associated with sales performance, embeddedness, advocacy and retention. Our results demonstrate that tangible benefits related to financial and marketing value are the strongest predictors of ISC organizational identification. Intangible dimensions such as value congruence, ISC trust in firm management, and ISC embeddedness play a relatively limited role in the model. In addition, we show that outcomes related to sales performance, retention, and advocacy are influenced directly and indirectly by organizational identification. Taken together, this study supports the contention that organizational identification plays a critical role in ISC-firm relationship.

Our study provides insights into research on the constructs used in our model. The first is the multi-dimensional antecedents of ISC organizational identification. Though our model confirms the central influence of tangible benefits (including financial, marketing and operational) as critical antecedents of organizational identification, it also supports our contention that value congruence acts as an antecedent. Moreover, our study supports our contention that in the context of ISCs, organization identification is an important predictor of sales performance, but also of embeddedness. Below, we will review the managerial implications of our theoretical contribution.

\subsection{The tangible value of organizational identification}

This finding offers important guidance to managers in the allocation of firm resources. Specifically, the findings show that ISC-firm relationship is more than a 'show me the money' 


\section{ANTECEDENTS OF INDEPENDENT SALES CONTRACTOR PERFORMANCE 21}

transaction as ISCs perceive significant value in organizational identification. Firstly, the fact that marketing benefits are such a critical predictor of organizational identification supports a notion that a firm's external identification and brand is an important part of an ISC's value proposition, as it either advances their ability to succeed personally or inhibits it. This is further supported by the fact that organizational identification is an important predictor of ISC sales performance. In other words, ISC sales performance is enhanced when an ISC views their identity and the identity of the firm as highly interdependent. These findings suggest that organizational identification can be a key performance indicator when evaluating the return on marketing investment for a firm.

\subsection{ISC embeddedness as a liability}

One surprising finding is associated with the attitudinal construct of ISC embeddedness. ISC embeddedness is deeply rooted in theory and literature (Felps et al. 2009) and is predicted in this study by two control variables - historic ISC sales performance and ISC trust in management. Thus, ISCs who are financially successful perceive a shared identity with a firm, ISC trust firm management and will feel deeply rooted to the organization. This was predicted and is well supported in the literature. However, a perception of ISC embeddedness surprisingly does not predict ISC behavioral outcomes associated with retention or advocacy. To explain this, the study reflects on the findings fromthe literature review that suggests 'independence' is valued highly by ISCs, However, this independence can prove to be both an asset (e.g., offering increased agility) and a liability (e.g., risk of employee churn). As Mael and Ashforth (1992) demonstrate, organizational identification includes dimensions associated with interdependency and preparedness to accept risk on behalf of the firm. However, as opposed to the construct of organizational identification, ISC embeddedness may be considered a liability. In other words, as 
opposed to the voluntary nature of an ISC developing a shared identity with a firm, ISC embeddedness may be interpreted as a threat to the independence they value.

A critical dimension of ISC embeddedness is time. For example, one measure in this study is "The longer I am at [firm] the harder it is for me to leave." In a traditional employeeemployer context, this may be interpreted as a positive. However, in the mind of an ISC, this may be interpreted as a form of coercion or a sacrifice of their independence by being entrenched with a firm that they can no longer leave. This may explain why it is not a significant predictor of retention or advocacy. Rather, these behavioral outcomes are predicted solely by ISC sales performance.

This is an important finding for managers of ISCs, because it suggests the extent to which ISCs differ from a traditional employee. Therefore, there is an important balance a firm must pursue in investing in and supporting ISCs to adopt (on their terms) a shared identity with the firm, without structuring incentives or rewards that risk making the ISC feel as though their relationship with the firm is no longer their choice. This finding is supported by the literature associated with independent contractors, which found that the majority of contractors continue because they value their independence (Kunda, Barley \& Evans 2002). Theoretically, this finding is supported by literature that suggests that power is an important factor in relationships as it may shift an interdependency to a dependency (Granovetter, 1985; Salancik \& Pfeffer, 1978).

\subsection{The power of history}

Our research supports previous findings in sales literature that suggests that the best predictor of individual-level sales performance is historic sales performance (past-sales). In the context of ISCs, this is amplified. This is an important finding given the unique nature of ISCs. Previous research suggests that the majority of contractors did not become contractors by choice, 
ANTECEDENTS OF INDEPENDENT SALES CONTRACTOR PERFORMANCE 23

but rather that circumstance (e.g., unemployment) contributes to this decision (Kunda et al., 2002). Therefore, the majority of contractors view this as a short-term stopgap between full-time appointments. However, research shows that some contractors view contracting as their profession and have little desire to pursue full-time employment. The most cited reason, as noted above, is independence. However, independence and success are highly inter-related. In other words, independence is sustainable if it is correlated to financial success. Therefore, this model empirically supports the contention that financial success is an essential pre-requisite for ISCs. Whereas historic sales performance strongly predicts ISC sales performance, ISC sales performance predicts both retention and advocacy behaviors. This reinforces the finding that tangible value, be it in the form of marketing support, organizational identification, or sales commission, trumps intangible value associated with dimensions such as value congruence, ISC trust in management, or ISC embeddedness. The study is not suggesting that these intangible dimensions are not valued. Rather, the findings suggest that tangible values are a 'core values', whereas intangible values are secondary.

\section{Limitations and future research}

The limitations of this study provide impetus for future research. Our study is based on theories of social identity and organizational identification. To develop and test our model, we chose variables directly relevant to our study. We acknowledge our model is only a partial depiction of the antecedents of organizational identification and its influence of ISC-level outcomes. There are limitations that are worthy of future investigation. First, the scope of this study is limited to the measures found herein. Further examination of additional antecedents should be explored in future research. This may include expanding potential antecedents of organizational identification and the measures of organizational identification as construct to 
offer both researchers and managers additional guidance on the role of these as predictors of ISC-level outcomes. Second, the study sample is limited to a single industry and a single population of ISCs, limiting external validity. Therefore, there is value in exploring this topic in different contexts. Other contexts could include organizations that leverage a mixture of both inhouse sales representatives and ISCs, or the variation by industry of the antecedents of organizational identification among ISCs.

Moreover, the study identifies the unique dynamics associated with ISCs when compared to a more traditional 'employee' sales force. Consequently, additional research should explore how to effectively measure ISC attitudes as key leading indicators of future behavior. This may include increasing understanding of measures associated with ISC identity, goals, and independence. Further research should examine the antecedents of ISC retention.

Based on the scope and measures included in this study, the findings suggest that ISC sales performance is the dominant predictor of retention. However, previous research suggests that retention is more complex than simply financial compensation. As noted above, the findings suggest that ISC sales performance is a core need, but further research is required to explore the secondary drivers of ISC retention. The researchers caution that, since SEM can produce a wide range of alternative models which achieve statistical equivalence, the accepted model must be considered to be simply one of the options that the study's data support. Therefore, future research should explore alternative models and their associated implications. In addition, similar studies are needed to strengthen the external validity of the hypotheses and findings by specifying alternative subjects associated with organizational identification and ISCs. Finally, the research is not a longitudinal study, which possibly limits the results related to individuals' attitudes towards an industry change over time. 
ANTECEDENTS OF INDEPENDENT SALES CONTRACTOR PERFORMANCE 25

\section{References}

Abeza, G., O’Reilly, N., \& Nadeau, J. (2014). Sport communication: A multidimensional assessment of the field's development. International Journal of Sport Communication, 7(3), 289-316.

Ang, S., Slaughter, S., \& Ng, K. Y. (2002). Human capital and institutional determinants of information technology compensation: Modeling multilevel and cross-level interactions. Management Science, 48(11), 1427-1445.

Ashforth, B. E., Harrison, S. H., \& Corley, K. G. 2008. Identification in Organizations: An Examination of Four Fundamental Questions. Journal of Management, 34(3): 325-374,

Ashforth, B. E., Rogers, K. M., \& Corley, K. G. 2010. Identity in Organizations: Exploring Cross-Level Dynamics. Organization Science, 22(5): 1144-1156.

Ashforth, B. E., \& Johnson, S. A. (2001). Which hat to wear. Social Identity Processes in Organizational Contexts, 32-48.

Ashforth, B. E., \& Mael, F. (1989). Social identity theory and the organization. Academy of Management Review, 14(1), 20-39.

Ashforth, B. E., Harrison, S. H., \& Corley, K. G. (2008). Identification in organizations: An examination of four fundamental questions. Journal of Management, 34(3), 325-374.

Bagozzi, R. P., \& Yi, Y. (2012). Specification, evaluation, and interpretation of structural equation models. Journal of the Academy of Marketing Science, 40(1), 8-34.

Bandura, A. (1986). Social foundations of thought and action: A social cognitive theory. Upper Saddle River, NJ: Prentice-Hall. 
ANTECEDENTS OF INDEPENDENT SALES CONTRACTOR PERFORMANCE 26

Banker, R. D., Lee, S. Y., Potter, G., \& Srinivasan, D. (1996). Contextual analysis of performance impacts of outcome-based incentive compensation. Academy of Management Journal, 39(4), 920-948.

Barrick, M. R., Mount, M. K., \& Strauss, J. P. (1993). Conscientiousness and performance of sales representatives: Test of the mediating effects of goal setting. Journal of Applied Psychology, 78(5), 715.

Barker, J. R., \& Tompkins, P. K. (1994). Identification in the self-managing organization characteristics of target and tenure. Human Communication Research, 21(2), 223-240.

Baruch, Y. (1999). Response rate in academic studies-A comparative analysis. Human Relations, 52(4), 421-438.

Bidwell, M. J., \& Briscoe, F. (2009). Who contracts? Determinants of the decision to work as an independent contractor among information technology workers. Academy of Management Journal, 52(6), 1148-1168.

Blunch, N. (2008). Introduction to structural equation modelling using SPSS and AMOS. Sage.

Borman, W. C., \& Motowidlo, S. J. (1997). Task performance and contextual performance: The meaning for personnel selection research. Human performance, 10(2), 99-109.

Brandon-Jones, A., Lewis, M., Verma, R., \& Walsman, M. C. (2016). Examining the characteristics and managerial challenges of professional services: An empirical study of management consultancy in the travel, tourism, and hospitality sector. Journal of Operations Management, 42, 9-24.

Burke, P. J., \& Tully, J. C. (1977). The measurement of role identity. Social Forces, 55(4), 881897.

Charbonnier- Voirin, A., Poujol, J. F., \& Vignolles, A. (2016). From value congruence to employer brand: Impact on organizational identification and word of mouth. Canadian 
ANTECEDENTS OF INDEPENDENT SALES CONTRACTOR PERFORMANCE 27

Journal of Administrative Sciences/Revue Canadienne des Sciences de l'Administration. Retrieved from http://onlinelibrary.wiley.com/doi/10.1002/cjas.1379/abstract

Churchill, G. A. J. (1979). A paradigm for developing better measures of marketing constructs. Journal of Marketing Research, 16(1), 64-73.

Crosby, L. A., Evans, K. R., \& Cowles, D. (1990). Relationship quality in services selling: an interpersonal influence perspective. The Journal of Marketing, 68-81.

Crossley, C. D., Bennett, R. J., Jex, S. M., \& Burnfield, J. L. (2007). Development of a global measure of job embeddedness and integration into a traditional model of voluntary turnover. Journal of Applied Psychology, 92(4), 1031.

Corsten, D., Gruen, T., \& Peyinghaus, M. 2011. The effects of supplier-to-buyer identification on operational performance-An empirical investigation of inter-organizational identification in automotive relationships. Journal of Operations Management, 29(6): 549560.

Davis-Blake, A., \& Uzzi, B. (1993). Determinants of employment externalization: A study of temporary workers and independent contractors. Administrative Science Quarterly, 38(2), $195-223$.

De Cuyper, N., \& De Witte, H. (2007). Job insecurity in temporary versus permanent workers: Associations with attitudes, well-being, and behavior. Work \& Stress, 21(1), 65-84. DOI: $10.1080 / 02678370701229050$

DeConinck, J. B. 2011. The effects of ethical climate on organizational identification, supervisory trust, and turnover among salespeople. Journal of Business Research, 64(6): $617-624$.

Drori, I., \& Ellis, S. (2011). Conflict and power games in a multinational corporation: Sensegiving as a strategy of preservation. European Management Review, 8(1), 1-16. 
ANTECEDENTS OF INDEPENDENT SALES CONTRACTOR PERFORMANCE 28

Dukerich, J. M., Golden, B. R., \& Shortell, S. M. (2002). Beauty is in the eye of the beholder: The impact of organizational identification, identity, and image on the cooperative behaviors of physicians. Administrative Science Quarterly, 47(3), 507-533.

Dutton, J. E., Dukerich, J. M., \& Harquail, C. V. (1994). Organizational images and member identification. Administrative Science Quarterly, 239-263.

Edwards, J. R., \& Cable, D. M. (2009). The value of value congruence. Journal of Applied Psychology, 94(3), 654.

Edwards, M. R. (2009). HR, perceived organisational support and organisational identification: an analysis after organisational formation. Human Resource Management Journal, 19, 91-115.

Edwards, M. R., \& Peccei, R. (2010). Perceived Organizational Support, Organizational Identification, and Employee Outcomes. Journal of Personnel Psychology, 9(1), 17-26.

Ellram, L. M., Tate, W. L., \& Billington, C. (2008). Offshore outsourcing of professional services: A transaction cost economics perspective. Journal of Operations Management, 26(2), 148-163.

Eisenberger, R., Huntington, R., Hutchison, S., \& Sowa, D. (1986). Perceived organizational support. Journal of Applied Psychology, 71(3), 500-507.

Felps, W., Mitchell, T. R., Hekman, D. R., Lee, T. W., Holtom, B. C., \& Harman, W. S. (2009). Turnover contagion: How coworkers' job embeddedness and job search behaviors influence quitting. Academy of Management Journal, 52(3), 545-561.

Finch, D., Hillenbrand, C., O’Reilly, N., \& Varella, P. (2015). Psychological contracts and independent sales contractors: An examination of the predictors of contractor-level outcomes. Journal of Marketing Management, 31(17-18), 1924-1964. 
ANTECEDENTS OF INDEPENDENT SALES CONTRACTOR PERFORMANCE 29

Fiol, C. M., \& O'Connor, E. J. (2005). Identification in face-to-face, hybrid, and pure virtual teams: Untangling the contradictions. Organization Science, 16(1), 19-32.

Fombrun, C. J., Gardberg, N. A., \& Sever, J. M. (2000). The reputation quotient: A multistakeholder measure of corporate reputation. Journal of Brand Management, 7(4), 241255.

Fornell, C., \& Larcker, D. F. (1981). Evaluating structural equation models with unobservable variables and measurement error. Journal of Marketing Research, 39-50.

George, E., \& Chattopadhyay, P. (2005). One foot in each camp: The dual identification of contract workers. Administrative Science Quarterly, 50(1), 68-99.

George, E., Levenson, A., Finegold, D., \& Chattopadhyay, P. (2010). Extra-role behaviors among temporary workers: How firms create relationship wealth in the United States of America. International Journal of Human Resource Management, 21(4), 530-550.

Gioia, D. A., \& Chittipeddi, K. (1991). Sensemaking and sensegiving in strategic change initiation. Strategic Management Journal, 12(6), 433-448.

Grace, D., \& Weaven, S. (2011). An empirical analysis of franchisee value-in-use, investment risk and relational satisfaction. Journal of Retailing, 87(3), 366-380.

Granovetter, M. (1973). The strength of weak ties. American Journal of Sociology, 78(6), 13601380.

Granovetter, M. (1985). Economic action and social structure: The problem of embeddedness. American Journal of Sociology, 91(3), 481-510.

Grieve, P. G., \& Hogg, M. A. (1999). Subjective uncertainty and intergroup discrimination in the minimal group situation. Personality and Social Psychology Bulletin, 25(8), 926-940.

Hair, J. F., Anderson, R. E., Tatham, R. L., \& William, C. (1998). Multivariate data analysis. Prentice Hall: Upper Saddle River, NJ. 
He, H., \& Brown, A. D. (2013). Organizational identity and organizational identification: A review of the literature and suggestions for future research. Group \& Organization Management, 38(1), 3-35.

Hillenbrand, C., Money, K., \& Ghobadian, A. (2013). Unpacking the mechanism by which corporate responsibility impacts stakeholder relationships. British Journal of Management, 24(1), 127-146.

Hogg, M. A., \& Terry, D. I. (2000). Social identity and self-categorization processes in organizational contexts. Academy of Management Review, 25(1), 121-140.

Hornsey, M. J., \& Hogg, M. A. (2000). Assimilation and diversity: An integrative model of subgroup relations. Personality and Social Psychology Review, 4(2), 143-156.

Ibarra, H. (1999). Provisional selves: Experimenting with image and identity in professional adaptation. Administrative Science Quarterly, 44(4), 764-791.

Johnson, S. A., \& Ashforth, B. E. (2008). Externalization of employment in a service environment: the role of organizational and customer identification. Journal of Organizational Behavior, 29(3), 287-309.

Katsikea, E., Theodosiou, M., \& Morgan, R. E. (2015). Why people quit: Explaining employee turnover intentions among export sales managers. International Business Review, 24(3), $367-379$.

Kennedy, K. N., Goolsby, J. R., \& Arnould, E. J. (2003). Implementing a customer orientation: Extension of theory and application. Journal of Marketing, 67(4), 67-81.

King, S. F., \& Burgess, T. F. (2008). Understanding success and failure in customer relationship management. Industrial Marketing Management, 37(4), 421-431. 


\section{ANTECEDENTS OF INDEPENDENT SALES CONTRACTOR PERFORMANCE 31}

Koku, P. S. (2015). A view from the street: an exploratory study of consumer attitudes toward offshoring of professional services in the United States. Journal of Services Marketing, 29(2), 150-159.

Kunda, G., Barley, S. R., \& Evans, J. (2002). Why do contractors contract? The experience of highly skilled technical professionals in a contingent labor market. Industrial \& Labor Relations Review, 55(2), 234-261.

Lacey, R. (2007). Relationship drivers of customer commitment. Journal of Marketing Theory and Practice, 15(4), 315-333.

Landau, D., \& Drori, I. (2008). Narratives as sensemaking accounts: The case of an R\&D laboratory. Journal of Organizational Change Management, 21(6), 701-720.

Leana, C. R., \& Rousseau, D. M. (Eds.) (2000). Relationship wealth: The advantages of stability in a changing economy. New York, NY: Oxford University Press.

Lei, P. W., \& Wu, Q. (2007). Introduction to structural equation modeling: Issues and practical considerations. Educational Measurement: Issues and Practice, 26(3), 33-43.

Lepak, D. P., \& Snell, S. A. (2002). Examining the human resource architecture: The relationships among human capital, employment, and human resource configurations. Journal of Management, 28(4), 517-543.

MacMillan, K., Money, K., Downing, S., \& Hillenbrand, C. (2005). Reputation in relationships: Measuring experiences, emotions and behaviours. Corporate Reputation Review, 8(3), 214-232.

Mael, F., \& Ashforth, B. E. (1992). Alumni and their alma mater: A partial test of the reformulated model of organizational identification. Journal of Organizational Behavior, 13(2), 103-123. 
ANTECEDENTS OF INDEPENDENT SALES CONTRACTOR PERFORMANCE 32

Maitlis, S., \& Lawrence, T. B. (2007). Triggers and enablers of sensegiving in organizations. Academy of management Journal, 50(1), 57-84.

Mallin, M. L., \& Pullins, E. B. (2009). The moderating effect of control systems on the relationship between commission and salesperson intrinsic motivation in a customer oriented environment. Industrial Marketing Management, 38(7), 769-777.

March, J. G., \& Simon, H. A. (1993). Organizations. Retrived from https://papers.ssrn.com/sol3/papers.cfm?abstract_id=1496194

Markus, H., \& Nurius, P. (1986). Possible Selves. American Psychologist, 41(9), 954.

Markus, H., \& Wurf, E. (1987). The dynamic self-concept: A social psychological perspective. Annual Review of Psychology, 38(1), 299-337.

Mazzocchi, M. (2008). Statistics for Marketing and Consumer Research. Newbury Park, CA: Sage Publications.

MBO Partners (2015). State of Independence in America in 2015: Five Years of Insight on the Growth of the Independent Workforce. ([Accessed 16 January 2017] https://www.mbopartners.com/uploads/files/state-of-independence-reports/MBO-SOIREPORT-FINAL-9-28-2015.pdf?/1).

Millward, L. J., \& Postmes, T. (2010). Who we are affects how we do: the financial benefits of organizational identification. British Journal of Management, 21(2), 327-339.

Mitchell, T. R., Holtom, B. C., Lee, T. W., Sablynski, C. J., \& Erez, M. (2001). Why people stay: Using job embeddedness to predict voluntary turnover. Academy of Management Journal, 44(6), 1102-1121.

Monroy, M., \& Alzola, L. (2005). An analysis of quality management in franchise systems. European Journal of Marketing, 39(5/6), 585-605. 
ANTECEDENTS OF INDEPENDENT SALES CONTRACTOR PERFORMANCE 33

Morgan, R. M., \& Hunt, S. D. (1994). The commitment-trust theory of relationship marketing. Journal of Marketing, 58(3), 20-38.

Pass, M. W. (2015). Independent Sales Representatives: The Influence of Information Quality on Manufacturer Trust. Academy of Marketing Studies Journal, 19(3), 210.

Palmatier, R., Dant, R., Grewal, D., \& Evans, K. (2006). Factors influencing the effectiveness of relationship marketing: A meta-analysis. Journal of Marketing, 70(4), 136-153.

Patchen, M. (1970). Participation, achievement, and involvement on the job. Englewood Cliffs, NJ: Prentice Hall.

Pfeffer, J., \& Nowak, P. (1976). Joint ventures and interorganizational interdependence. Administrative Science Quarterly, 398-418.

Podsakoff, N. P., Whiting, S. W., Podsakoff, P. M., \& Blume, B. D. (2009). Individual- and organisational-level consequences of organisational citizenship behaviors: A metaanalysis. Journal of Applied Psychology, 94(1), 122-141. http://dx.DOI.org/10.1037/a0013079

Posner, B. Z., \& Schmidt, W. H. (1993). Values congruence and differences between the interplay of personal and organizational value systems. Journal of Business Ethics, 12(5), $341-347$

Ramaswami, S. N., \& Singh, J. (2003). Antecedents and consequences of merit pay fairness for industrial salespeople. Journal of Marketing, 67(4), 46-66.

Rapp, A., Agnihotri, R., \& Baker, T. L. (2015). Competitive intelligence collection and use by sales and service representatives: how managers' recognition and autonomy moderate individual performance. Journal of the Academy of Marketing Science, 43(3), 357-374. 


\section{ANTECEDENTS OF INDEPENDENT SALES CONTRACTOR PERFORMANCE 34}

Rich, G. A. (1997). The sales manager as a role model: Effects on trust, job satisfaction, and performance of salespeople. Journal of The Academy Of Marketing Science, 25(4), 319328.

Riketta, M. 2005. Organizational Identification: A meta-analysis. Journal of Vocational Behavior, 66(2): 358-384.

Rossiter, J. R. (2002). The C-OAR-SE procedure for scale development in marketing. International Journal of Research in Marketing, 19(4), 305-335. DOI: 10.1016/S01678116(02)00097-6

, D. (1995). Psychological contracts in organizations: Understanding Written and Unwritten Agreements. Sage.

Saks, A. M., \& Ashforth, B. E. (1997). Organizational socialization: Making sense of the past and present as a prologue for the future. Journal of vocational Behavior, 51(2), 234-279.

Salancik, G. R., \& Pfeffer, J. (1978). A social information processing approach to job attitudes and task design. Administrative Science Quarterly, 23(2), 224-253.

Schmenner, R. W. (1986). How can service businesses survive and prosper? Sloan Management Review (1986-1998), 27(3), 21.

Slater, S. F., \& Olson, E. M. (2000). Strategy type and performance: The influence of sales force management. Strategic Management Journal, 21(8), 813-829.

Stajkovic, A. D., \& Luthans, F. (2001). Differential effects of incentive motivators on work performance. Academy of Management Journal, 44(3), 580-590.

Stamper, C. L., \& Masterson, S. S. 2002. Insider or outsider? how employee perceptions of insider status affect their work behavior. Journal of Organizational Behavior, 23(8): 875894. 
ANTECEDENTS OF INDEPENDENT SALES CONTRACTOR PERFORMANCE 35

Stryker, S., \& Burke, P. J. (2000). The past, present, and future of an identity theory. Social Psychology Quarterly, 284-297.

Tajfel, H., \& Turner, J. C. (1986). The social identity theory of intergroup behavior. In S. Worshel, \& W. Austin (Eds.), The Psychology Of Intergroup Relations. Chicago: NelsonHall.

Turner, J. C., Hogg, M. A., Oakes, P. J., Reicher, S. D., \& Wetherell, M. S. (1987). Rediscovering the social group: A self-categorization theory. Basil Blackwell.

US Bureau of Labor Statistics (2012). Occupational Outlook Handbook (2012-13 Ed.). ([Accessed 15 December 2015] http://www.bls.gov/ooh/about/career-guide-toindustries.htm).

Vandenberg, R. J., \& Lance, C. E. (2000). A review and synthesis of the measurement invariance literature: Suggestions, practices, and recommendations for organizational research. Organizational Research Methods, 3(1), 4-70.

VandeWalle, D., Brown, S. P., Cron, W. L., \& Slocum Jr, J. W. (1999). The influence of goal orientation and self-regulation tactics on sales performance: A longitudinal field test. Journal of Applied Psychology, 84(2), 249.

Vora, D., \& Kostova, T. (2007). A model of dual organizational identification in the context of the multinational enterprise. Journal of Organizational Behavior, 28(3), 327-350.

Walsh, J., \& Deery, S. (2006). Refashioning organizational boundaries: Outsourcing customer service work. Journal of Management Studies, 43(3), 557-582.

Wieseke, J., M. Ahearne, S. K. Lam \& R. van Dick (2009). The role of leaders in internal marketing. Journal of Marketing, 73, 123-145. 


\section{ANTECEDENTS OF INDEPENDENT SALES CONTRACTOR PERFORMANCE 36}

Wiesenfeld, B. M., Raghuram, S., \& Garud, R. (2001). Organizational identification among virtual workers: The role of need for affiliation and perceived work-based social support. Journal of Management, 27(2), 213-229.

Zoghbi-Manrique-de-Lara, P. (2010). Do unfair procedures predict employees' ethical behavior by deactivating formal regulations? Journal of Business Ethics, 94(3), 411-425. 


\section{FIGURES}

\section{Figure 1 Hypothesized ISC organizational identification model}

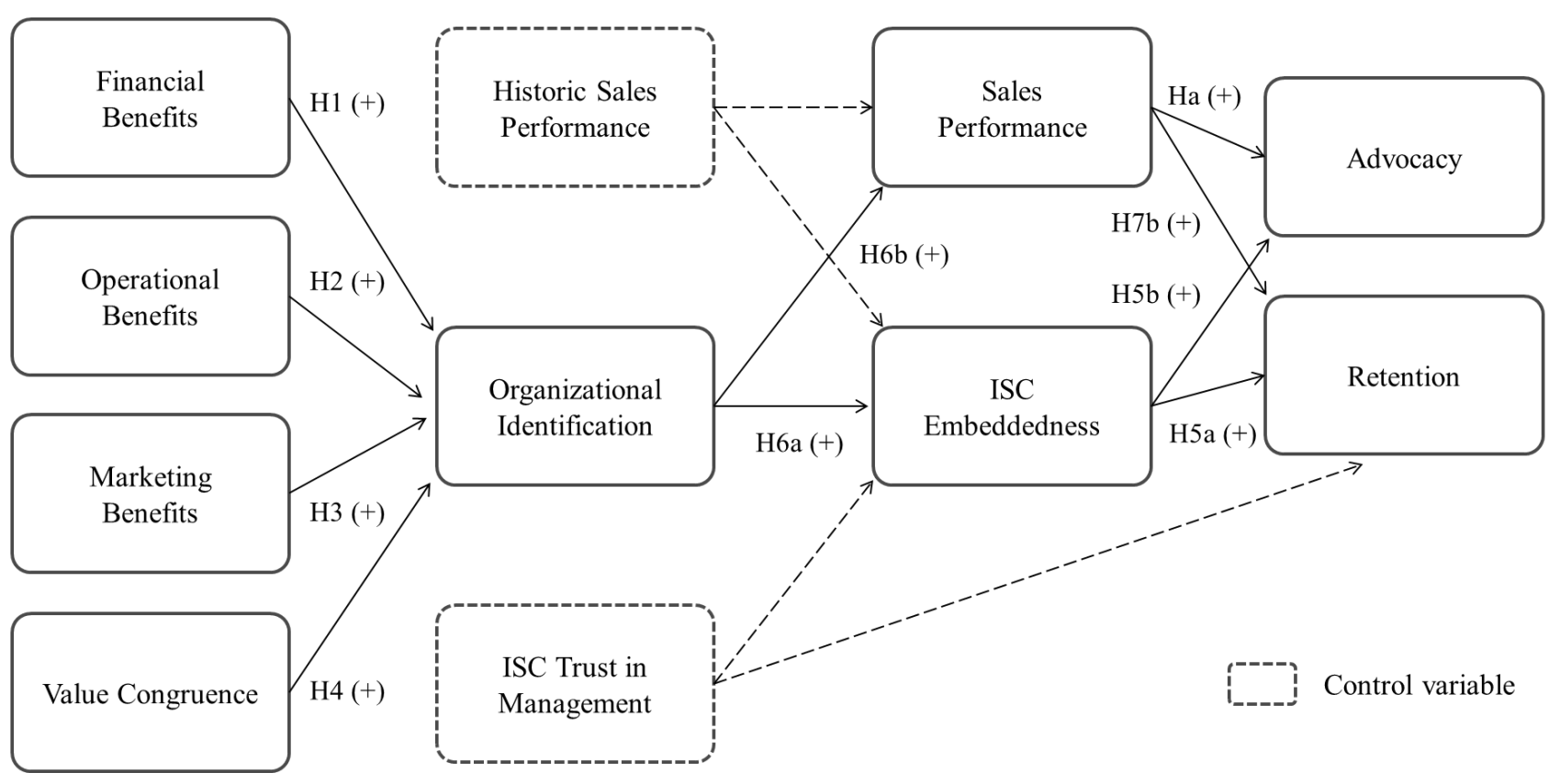


ANTECEDENTS OF INDEPENDENT SALES CONTRACTOR PERFORMANCE 38

Figure 2 Final ISC organizational identification model

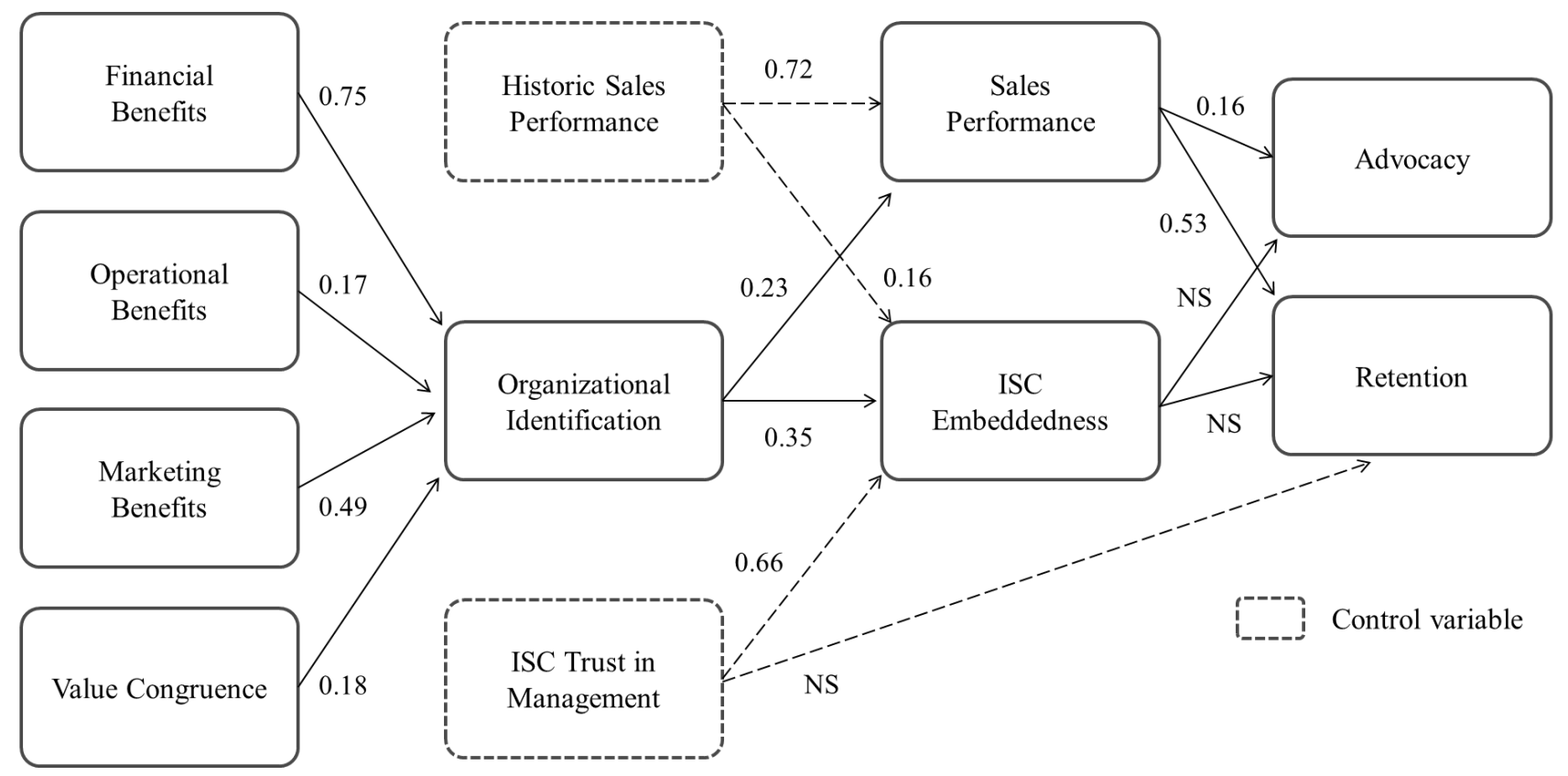




\section{Table 1 Construct Development}

\section{Marketing benefits}

$\mathrm{CA}=0.88$

[Firm] radio advertising gives me confidence about the future of the company.

[Firm] TV advertising gives me confidence about the future of the company.

[Firm] outdoor (e.g., bus) advertising gives me confidence about the future of the company.

0.81

\section{Operational benefits}

$\mathrm{CA}=0.93$

I am satisfied with the information technology support I receive.

0.90

I am satisfied with the office support I receive.

0.96

Financial benefits

$\mathrm{CA}=0.61$

I would change companies today but switching would require more time and effort than I am willing to put forth (Reversed).

I would switch companies if it meant making more money (Reversed).

I only have a relationship with [firm] because I need a license to practice (Reversed).

0.66

0.53

Value congruence

$\mathrm{CA}=0.74$

It is important to me that the company I work with have values that are consistent with my own personal values.

It is important that I work with a company with a vision towards growth.

0.78

It is important the management of the company I work with have strong leadership.

0.81

\section{ISC embeddedness}

The longer I am at [firm] the harder it is for me to leave.

The more time I spend with my manager the harder it is for me to leave.

0.52

The longer I am at [firm] the more I get from it.

0.72

Organizational identification

$\mathrm{CA}=0.76$

When I see [firm] advertising it makes me feel proud.

0.73

I am proud to tell people I work with [firm].

0.65

I would actively support [firm] even if it had no direct benefit to me and my business.

0.53

I actively 'talk-up' the firm.

0.59

I will invest $\mathrm{m}$ personal time in building [firm] because my business is dependent on it being successful.

0.46

I see little benefit in spending my time in building [firm] (Reverse).

0.51

\section{ISC trust in firm management}

$\mathrm{CA}=0.91$

[Firm] managers listen to the opinions of their agents.

0.77

[Firm] managers only care about themselves (Reverse).

0.78

[Firm] managers keep their promises.

0.76

[Firm] management is unpredictable (Reverse).

0.75

Whenever [firm] managers make a decision; I know they will be looking out for the best interest of its agents. 
Table 2 Correlation table

\begin{tabular}{|c|c|c|c|c|c|c|c|c|c|c|c|c|c|c|}
\hline & Mean & SD & AVE & 1 & 2 & 3 & 4 & 5 & 6 & 7 & 8 & 9 & 10 & 11 \\
\hline 1. Operations & 4.10 & .89 & .948 & & & & & & & & & & & \\
\hline 2. Marketing & 3.81 & .85 & .977 & $.243^{* *}$ & & & & & & & & & & \\
\hline 3. Finance & 2.81 & .54 & .968 & .101 & .009 & & & & & & & & & \\
\hline 4. Value & 4.47 & .50 & .955 & $.243^{* *}$ & $.339^{* *}$ & .069 & & & & & & & & \\
\hline 5. Trust & 3.14 & .29 & .975 & $.275^{* *}$ & .119 & .072 & .046 & & & & & & & \\
\hline 6. Identification & 3.87 & .55 & .952 & $.331^{* *}$ & $.535^{* *}$ & $.317^{* *}$ & $.455^{* *}$ & $.278^{* *}$ & & & & & & \\
\hline 7. Embedded & 3.60 & .69 & .956 & $.355^{* *}$ & $.370^{* *}$ & $.262^{* *}$ & $.199^{* *}$ & $.294^{* *}$ & $.552^{* *}$ & & & & & \\
\hline 8. Pre-sales & 11.18 & 13.77 & .617 & .075 & .034 & .045 & .127 & .089 & .101 & $.252^{* *}$ & & & & \\
\hline 9. Post-sales & 1.49 & 13.21 & .941 & .084 & .082 & .061 & .125 & .044 & .023 & .052 & $.608^{* *}$ & & & \\
\hline 10. Advocacy & 839.97 & 1193.00 & .958 & .053 & .068 & -.021 & .100 & -.070 & -.025 & -.013 & .071 & .129 & & \\
\hline 11. Retention & 1.32 & .47 & .976 & .002 & .015 & .037 & .102 & .091 & .022 & .046 & $.312^{* *}$ & $.499^{* *}$ & .027 & \\
\hline 12. Years & 4.88 & 5.50 & .955 & -.002 & -.009 & -.061 & .072 & .052 & .028 & .044 & $.302^{* *}$ & .138 & -.130 & $-.237^{* *}$ \\
\hline
\end{tabular}

** Correlation is significant at the .01 level. * Correlation is significant at the .05 level. 


\section{Table 3 Results}

\section{Financial benefits}

H1. ISC satisfaction with financial benefits will be positively related to organizational identification.

\section{Operational benefits}

H2. ISC satisfaction with operational benefits will be positively related to organizational identification.

\section{Marketing benefits}

H3. ISC satisfaction with marketing benefits will be positively related to organizational identification.

\section{Value congruence}

H4. ISC value congruence will be positively related to organizational identification.

ISC embeddedness

H5a. ISC embeddedness will be positively related to retention.

H5b. ISC embeddedness will be positively related to advocacy.

\section{Organizational identification}

H6a. Organizational identification will be positively related to ISC embeddedness.

H6b. Organizational identification in management will be positively related to performance.

\section{Sales performance}

H7a. ISC sales performance will be positively related to retention.

H7b. ISC sales performance will be positively related to advocacy.

\section{Result}

Support

$0.75, \mathrm{p}<0.001$

Supported

$0.17, \mathrm{p}<0.01 \quad$ Supported

$0.49, \mathrm{p}<0.01 \quad$ Supported

$0.18, \mathrm{p}<0.01 \quad$ Supported

0.07, $\mathrm{p}<0.333 \quad$ Not Supported

0.352, $\mathrm{p}<0.361 \quad$ Not Supported

$0.35, \mathrm{p}<0.01 \quad$ Supported

$0.23, p<0.05 \quad$ Supported

0.16, $\mathrm{p}<0.05 \quad$ Supported

$0.53, \mathrm{p}<0.001 \quad$ Supported 